\title{
Coleta, transporte e armazenamento de amostras para diagnóstico molecular
}

\author{
Collection, transport and storage of samples for molecular diagnosis
}

Murilo Rezende Melo'; Alvaro Rodrigues Martins'; Ismar Venâncio Barbosa ${ }^{3}$; Patricia Romano4; Wilson Shcolnik ${ }^{5}$

\section{unitermos resumo}

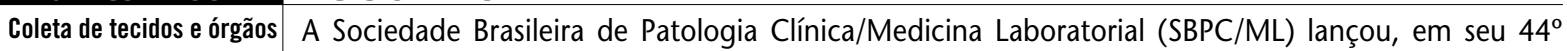

Coleta de amostras

sanguíneas

Congresso Brasileiro de Patologia Clínica e Medicina Laboratorial, uma série de recomendações para minimizar os erros na fase pré-analítica, sendo este texto uma delas. Além do crescimento do mercado

Técnicas de diagnóstico molecular de testes moleculares, é frequente a percepção errônea de que esses testes são menos sujeitos a erros. Enfatizamos, neste documento, que certos cuidados na fase pré-analítica são extremamente importantes

Patologia molecular para garantir a confiabilidade de testes moleculares.

Manejo de espécimes

(amostra)

Ácidos nucleicos

abstract

The Brazilian Society of Clinical Pathology/Laboratory Medicine (SBPC/ML) launched a series of recommendations on how to minimize errors on the pre-analytical testing phase during the $44^{\text {th }}$ Brazilian Congress of Clinical Pathology and Laboratory Medicine. This is one of them. The molecular diagnostics market is growing fast and many people believe these tests are less error-prone. In this study we highlight that proper care during the pre-analytical phase is extremely important in order to ensure the reliability of molecular diagnostic tests.

\section{Acidos nucleicos}




\section{Introdução}

O mercado de testes moleculares para fins diagnósticos está em expansão, com crescimento anual composto mundial estimado em 11,49\%, entre 2009 e 2014. A introdução de novos marcadores, a regulação de pagamento por esses testes e o desenvolvimento de novas tecnologias para sua detecção são importantes fatores para esse crescimento ${ }^{(18)}$.

Apesar de muitas pessoas acreditarem que o resultado de um teste molecular seja absoluto e inerrante, ele está sujeito a erros, como qualquer teste laboratorial, especialmente na fase pré-analítica ${ }^{(16)}$. A qualidade e a quantidade dos ácidos nucleicos extraídos são bastante afetadas pela coleta da amostra, por seu manuseio e transporte e pela escolha do método de extração ${ }^{(19,23,24)}$.

A extração de ácidos nucleicos, seguida de métodos moleculares, nos permite detectar presença ou quantidade de vírus, caracterização de microrganismos, determinação do genótipo viral e presença, predisposição ou estado de portador de doenças hereditárias. Mais recentemente, a análise de marcadores que exigem a análise de RNA intracelular começou a ser realizada, como a análise de produtos de fusão gênica que caracterizam algumas neoplasias hematológicas. A natureza lábil do RNA dificulta grandemente a padronização desses testes. Além disso, um resultado negativo em uma amostra manuseada sem o devido cuidado pode ser decorrente da degradação do RNA-alvo e não pela ausência de doença ${ }^{(3)}$. Assim, torna-se relevante entender as possíveis causas de erro, na fase pré-analítica, mais frequentes no diagnóstico molecular.

\section{Discussão}

\section{Coleta e transporte de amostras para testes moleculares}

Como na coleta de qualquer amostra biológica para fins diagnósticos, deve-se considerar a amostra potencialmente contaminada e utilizar as precauções de biossegurança padronizadas pela legislação e pelos programas de acreditação laboratorial (como o Programa de Acreditação de Laboratórios Clínicos [PALC] da Sociedade Brasileira de Patologia Clínica [SBPC] $)^{(26)}$. Igualmente, é essencial manter o cuidado na identificação da amostra e na garantia da obtenção de todos os dados necessários para a correta interpretação dos resultados a partir da solicitação médica. Já existem testes moleculares que consideram o fenótipo (ou informações clínicas) para o cálculo do risco de doenças ou da dose necessária de um fármaco para se obter um efeito clínico, como, por exemplo, a dose de warfarina para obtenção de determinada razão normalizada internacional (INR) do tempo de protrombina. A individualização das informações necessárias para cada teste e sua obtenção cuidadosa são essenciais para que o resultado do teste seja mais informativo e relevante para a condução clínica dos $\operatorname{casos}^{(6,14,20,21)}$.

A rejeição de amostras deve ser minimizada pelo laboratório. Entretanto, amostras de sangue hemolisado e de sangue total congelado, além daquelas impropriamente identificadas, devem ser consideradas inaceitáveis para os testes moleculares. Apenas em situações raras, a critério do diretor do laboratório e com anuência do médico solicitante, pode-se considerar a realização do teste em amostra com problema de identificação, desde que exista procedimento para garantir sua identidade, como, por exemplo, testes de marcadores polimórficos de um único nucleotídeo (SNPs). Os critérios de aceitação e rejeição de amostras devem ser documentados no procedimento operacional padrão de cada ensaio ${ }^{(7,26)}$.

\section{Sangue e aspirado de medula óssea}

Vários estudos demonstraram que a heparina e o heme são potentes inibidores da reação em cadeia da polimerase (PCR), de modo que os anticoagulantes recomendados para essas amostras são os ácidos etilenodiaminotetracético (EDTA) e citrato dextrose $(A C D)^{(25)}$. No caso do alvo molecular ser um RNA intracelular, é recomendado que o sangue ou a medula óssea seja coletado com um aditivo para estabilização de RNA ou colocado em uma solução estabilizadora de RNA o mais rapidamente possível(8). Devem-se considerar as recomendações do fabricante do teste, o volume da amostra necessário e o tipo de ácido nucleico de interesse para determinação dos aditivos e tubos para cada teste ${ }^{(27)}$.

Apesar de o EDTA ser o anticoagulante preferido para coleta de sangue e separação de plasma para métodos moleculares, é importante seguir as recomendações do fabricante do teste, pois o EDTA pode interferir com alguns testes. Quando ele é usado, o sangue pode ser coletado em tubos com ou sem gel separador. Para análises de RNA viral (como HIV), o 
sangue deve ser centrifugado e, no caso do tubo sem gel separador, o plasma deve ser removido para outro tubo estéril e livre de RNAses em até quatro horas da coleta. Plasma separado por gel pode ser transportado até o laboratório sem manipulação, sendo esta a preferência de vários serviços para evitar o risco de contaminação. As amostras de plasma são estáveis a $2-8^{\circ} \mathrm{C}$ por até cinco dias, suportando tempos maiores quando congeladas; recomenda-se que sejam transportadas refrigeradas e congeladas posteriormente, evitando ciclos de congelamento-descongelamento. O soro deve ser mantido congelado e transportado com gelo seco, tanto para as análises de DNA quanto para as de RNA.

O sangue total é estável a temperatura ambiente por 24 horas para análise de DNA e até oito dias, quando resfriado $\left(2-8^{\circ} \mathrm{C}\right)$. Para análise de RNA celular, o sangue deve ser coletado com aditivo estabilizador. Coleta e armazenamento de sangue total sem estabilizador não são recomendados para análise de transcrição genética, em função da indução e da degradação de RNA que ocorre ex vivo.

Deve-se aspirar a medula óssea utilizando-se uma seringa com EDTA, e a equipe responsável pelo processamento deve ser avisada assim que a amostra chegar ao laboratório. Para extração de DNA, o aspirado de medula óssea pode ser armazenado temporariamente por até 72 horas a $2-8^{\circ} \mathrm{C}$ antes do processamento. Caso seja necessário armazenar por tempo superior a esse, devem-se remover os eritrócitos e congelar a amostra a $-20^{\circ} \mathrm{C}$ (por até vários meses). Deve-se atentar para a remoção dos eritrócitos, que podem liberar heme e inibir a reação de $P C R^{(1)}$. Para extração de RNA, o aspirado de medula óssea também deve ser coletado em seringa com EDTA, mas colocado o mais rápido possível em solução estabilizadora de RNA. Quando não for possível, deve ser transportado em meio a gelo triturado, e a extração deve ser realizada em até quatro horas da coleta, caso a amostra não possa ser congelada. A amostra não deve ser congelada antes da eliminação dos eritrócitos ${ }^{(7)}$.

\section{Amostras de tecidos}

Amostras de tecidos são usadas quando não for possível a coleta de sangue (p. ex., paciente falecido), o tecido e o sangue apresentarem diferente genótipo (p. ex., mutações somáticas em doenças neoplásicas ou mosaicismos) ou o tecido for a única fonte de ácidos nucleicos para potenciais agentes infecciosos.

Idealmente, 1 a $2 \mathrm{~g}$ de tecidos devem ser obtidos, mas essa quantidade ótima depende da celularidade e da quantidade de núcleos da amostra. Assim, podemos necessitar de menor quantidade de tecidos de linfonodos do que de tecido gorduroso. Entretanto, qualquer quantidade de tecido (não gorduroso) acima de $10 \mathrm{mg}$ costuma fornecer mais de $10 \mu \mathrm{g}$ de DNA ou RNA, o que é suficiente para muitas análises diagnósticas. Uma vez que quantidades e tipos de proteínas são muito variáveis entre os tecidos, os protocolos de extração de ácidos nucleicos são tecido-específicos. Siga as recomendações do fabricante para o isolamento de DNA e/ou RNA nesses casos.

Para algumas aplicações, como identificação de perda de heterozigosidade, é essencial que o patologista examine o tecido, separando o lesado do não lesionado, que servirá de controle ${ }^{(13,38)}$.

A estabilidade dos ácidos nucleicos varia com o tipo de tecido. Em geral, não é recomendável manter o tecido a temperatura ambiente para posterior análise molecular. O ideal é o congelamento em nitrogênio líquido ou a colocação do tecido em uma solução de preservação de ácidos nucleicos. Quando isso não for possível, recomenda-se que a amostra de tecido seja colocada em banho de gelo e transportada com gelo para melhor preservação dos ácidos nucleicos, especialmente do RNA. Amostras muito pequenas podem ser embrulhadas em gaze embebida com salina, a fim de evitar que a amostra resseque. Mesmo assim, as amostras devem ser colocadas em solução de preservação de ácidos nucleicos o mais rapidamente possível para evitar degradação dos mesmos. Isso é particularmente crítico para transcritos de RNA, visto que existe ampla variação de meia-vida entre eles e alguns têm meia-vida de segundos ou minutos ${ }^{(29)}$. Por outro lado, como a maioria dos aditivos de preservação de ácidos nucleicos não é adequada para a fixação de análises histológicas e imunoquímicas tradicionais, recomenda-se padronizar esse procedimento com o laboratório de patologia.

Devido aos efeitos da anestesia e da falta de padronização nas tecnologias de estabilização de RNA, a hipóxia decorrente dos procedimentos cirúrgicos pode alterar a expressão de muitos genes. Hipóxia prolongada diminui o $\mathrm{pH}$ local dos tecidos, o que diminui a quantidade de ácidos nucleicos extraídos e altera a expressão dos mRNA expressos ${ }^{(15)}$. 
Para extração de DNA, o tecido deve ser resfriado imediatamente e transportado ao laboratório em banho de gelo triturado, onde deve ser acondicionado a $2-8^{\circ} \mathrm{C}$ e processado em até 24 horas. Amostras que serão analisadas por técnicas moleculares in situ, como hibridização fluorescente in situ (FISH), devem ser colocadas em meio optimal cutting temperature (OCT) e congeladas até seu processamento. Em geral, o DNA é estável em tecidos por até 24 horas a $2-8^{\circ} \mathrm{C}$, por, pelo menos, duas semanas a $-20^{\circ} \mathrm{C}$ e por, pelo menos, dois anos a $-70^{\circ} \mathrm{C}$ ou inferior. Tecidos sólidos, especialmente tumorais, são ricos em endonucleases e devem ser processados ou congelados o mais rápido possível após serem recebidos no laboratório. Idealmente, o laboratório deve ser notificado com antecedência sobre o envio dessas amostras e se preparar para recebê-la e processá-la rapidamente. Tecido com sangue deve ser lavado com salina antes de ser congelado $^{(7)}$. Ocasionalmente, o teste molecular será solicitado apenas após o exame patológico, quando será realizado em tecido parafinado, sendo utilizados protocolos específicos nesses casos para desfazer o cross-linking e diminuir o efeito do cisalhamento dos ácidos nucleicos ${ }^{(11,12,30)}$.

Para extração de RNA, a amostra deve ser congelada rapidamente em nitrogênio líquido antes de ser congelada a $-70^{\circ} \mathrm{C}$ (ou inferior), colocada em solução estabilizadora de RNA ou processada para extração de RNA em, no máximo, uma hora da coleta. Como o RNA pode ser degradado por RNAses, deve-se armazenar as amostras em tubos plásticos estéreis, hidrofóbicos, que não foram tocados por mãos sem luvas. Independentemente da duração esperada do armazenamento, a temperatura deve ser de $-70^{\circ} \mathrm{C}$ ou inferior. Amostras congeladas não devem ser descongeladas para extração de RNA, mas homogeneizadas diretamente em isotiocianato de guanidina ou outro agente de extração(7).

\section{Amostras cervicais e swabs uretrais}

Amostras uretrais masculinas devem ser coletadas com swabs com ponta de poliéster, com haste flexível. Amostras endocervicais ou vaginais femininas devem ser coletadas com swabs com cerdas de rayon ou poliéster e colocadas no meio de transporte especificado pelo fabricante do ensaio. Amostras para análise de papilomavírus humano (HPV) devem ser coletadas com os swabs recomendados pelo fabricante do ensaio e colocadas no meio de transporte especificado pelo ele ${ }^{(7)}$.

\section{Células bucais}

As células bucais podem ser fonte de DNA e RNA. Amostras de bochecho também são comumente usadas como fonte de células bucais. Deve-se utilizar solução estabilizante de RNA tanto para células bucais obtidas por raspado ou swab como por bochecho. Para análise de DNA, amostras coletadas em swabs específicos podem ser secas e transportadas a temperatura ambiente. Amostras de bochecho podem ser transportadas a temperatura ambiente e são estáveis por até uma semana( $(7,10,22)$.

\section{Líquido cefalorraquidiano (LCR)}

Amostras de LCR devem ser transportadas a $2-8^{\circ} \mathrm{C}$ para análise de DNA. Caso não possam ser processadas imediatamente, elas podem ser congeladas $\left(\mathrm{a}-20^{\circ} \mathrm{C}\right.$ ou inferior) para pesquisa de vírus de DNA (p. ex., HSV, CMV e VZV).

Para análise de RNA (incluindo vírus de RNA, como os enterovírus), a amostra deve ser colocada em banho com gelo triturado e o RNA extraído em até quatro horas da coleta. Se não for possível, deve-se remover possível contaminação com eritrócitos e congelar a amostra, transportando-a com gelo seco ${ }^{(7,9)}$.

\section{Punção aspirativa de agulha fina (PAAF)}

Para extração de DNA, o procedimento é semelhante àquele recomendado para o aspirado de medula óssea (descrito anteriormente). Para estudos de RNA, a amostra obtida por PAAF deve ser resfriada imediatamente ou colocada em solução com estabilizador de RNA ou, alternativamente, diretamente na solução de lise do kit de extração. Entretanto, no caso de contaminação da punção com sangue, é aconselhável que os eritrócitos sejam removidos antes da adição da solução estabilizadora de RNA. Eritrócitos também devem ser removidos caso a amostra resfriada não possa ser processada em até quatro horas e precisar ser congelada (a $-70^{\circ} \mathrm{C}$ ou inferior $)^{(7,37)}$.

\section{Sêmen}

A amostra de sêmen deve ser imediatamente resfriada e mantida a $2-8^{\circ} \mathrm{C}$ até a extração do $\mathrm{DNA}^{(7)}$ e usualmente é concentrada por centrifugação 
após sua liquefação( ${ }^{(32)}$. A análise de DNA pode ser realizada em sêmen seco, assim como em sêmen fixado em lâmina para citologia por técnicas de hibridização in situ, existindo recuperação de DNA de alta qualidade em amostras forenses obtidas até 25 anos antes ${ }^{(17)}$.

\section{Escarro}

O escarro para análise de DNA deve ser coletado em frasco estéril e transportado ao laboratório a temperatura ambiente, caso demore até 30 minutos; caso contrário, deve-se refrigerar a amostra. Apesar das aplicações clínicas normalmente demandarem resultados rápidos para os agentes infecciosos pesquisados (como Mycobacterium tuberculosis) e a amostra permanecer apenas resfriada nesses casos, o DNA no escarro pode ser estável por até um ano quando congelado a $-70^{\circ} \mathrm{C}$. Alguns protocolos de extração de DNA utilizam a concentração do escarro para aumentar a sensibilidade da pesquisa de agentes infecciosos, e as recomendações do fabricante devem ser seguidas nesses casos. Há variação de eficiência entre os diversos protocolos de extração, em função da presença de inibidores da polimerase no escarro ${ }^{(2,35)}$.

\section{Fezes}

Amostras de fezes devem ser transportadas de acordo com as recomendações do teste a ser realizado; alguns exigem preservante da amostra e outros requerem apenas refrigeração, sem preservante. Alguns protocolos de extração de DNA envolvem a diluição da amostra com solução tamponada ( $\mathrm{pH}$ $7,4)$ e centrifugação para eliminação dos debris. A amostra passa por filtração para eliminação de restos celulares, sendo que a maioria dos microrganismos ficará no filtrado, que será submetido à extração de $\mathrm{DNA}^{(28,34)}$.

\section{Urina}

Volume de urina, tempo desde a última micção, presença de inflamação e outros fatores podem afetar a obtenção de ácidos nucleicos ${ }^{(33)}$. O tempo da amostra a temperatura ambiente deve ser minimizado, já que o pH baixo e a alta quantidade de ureia rapidamente degradam o DNA, especialmente acima de $25^{\circ} \mathrm{C}$. Caso exista necessidade de armazenamento da amostra, esta deve ser congelada a $-70^{\circ} \mathrm{C}$, mas, mesmo assim, pode haver diminuição da capacidade de detectar alguns microrganismos. O processamento deve obedecer às recomendações do fabricante, em função do tipo de teste, e poderá envolver algum passo para a concentração da amostra ${ }^{(5,36)}$.

\section{Armazenamento do DNA purificado}

Depois de isolar o DNA das amostras, recomenda-se que seja armazenado abaixo de $0^{\circ} \mathrm{C}$, para minimizar a atividade de degradação das DNAses, em tubo de plástico, hidrofóbico e com tampa de vedação eficaz, preferencialmente com uma vedação de borracha para prevenir a evaporação. Os tubos de polialômeros e alguns de polipropileno são mais apropriados para armazenamento do DNA; tubos de polietileno e a maioria dos de polipropileno não tratados causam significativa adsorção de DNA no tubo ${ }^{(4)}$.

O DNA purificado pode ser armazenado em tampão tris-EDTA (TE), pH 7,2, por 26 semanas a temperatura ambiente, por um ano a $2-8^{\circ} \mathrm{C}$ (na ausência de DNAses), por até sete anos em freezer a $-20^{\circ} \mathrm{C}$ e por mais do que isso a $-70^{\circ} \mathrm{C}$. O freezer utilizado não deve ser do tipo frost-free, visto que esse mecanismo faz com que a temperatura oscile, causando deterioração por cisalhamento dos ácidos nucleicos $(7,31)$.

\section{Armazenamento do RNA purificado}

Após obtenção da amostra, pode ocorrer tanto a degradação como a indução de RNA, causando alterações no perfil de expressão gênica in vivo, às vezes em poucos minutos. Assim, é recomendável que, quando possível, as amostras sejam obtidas com solução estabilizadora de RNA (ou, no caso de tecidos, congeladas em nitrogênio líquido). Independentemente da duração estimada do armazenamento, recomenda-se que este seja realizado como um precipitado em etanol a $-70^{\circ} \mathrm{C}$ ou inferior, visto que a atividade de degradação do RNA das RNAses continua a $-20^{\circ} \mathrm{C}$. Devem ser utilizados tubos plásticos estéreis, hidrofóbicos, que não foram manuseados por mãos sem luvas e que foram tratados com água com dietilpirocarbonato para a eliminação de RNAses dos tubos, que são muito estáveis (ou que contenham a informação de RNAse-free $)^{(7)}$. 


\section{Referências}

1. AL SOUD, W. A.; RADSTROM, P. Purification and characterization of PCR-inhibitory components in blood cells. J Clin Microbiol, v. 39, p. 485-93, 2001.

2. ALDOUS, W. K. et al. Comparison of six methods of extracting Mycobacterium tuberculosis DNA from processed sputum for testing by quantitative real-time PCR. J Clin Microbiol, v. 43, p. 2471-3, 2005.

3. ANWAR, A. et al. Evaluation of pre-analytical variables in the quantification of dengue virus by realtime polymerase chain reaction. J Mol Diagn, v. 11, p. 537-42, 2009.

4. BELOTSERKOVSKII, B. P.; JOHNSTON, B. H. Polypropylene tube surfaces may induce denaturation and multimerization of DNA. Science, v. 271, p. 222-3, 1996.

5. BERGMANN, A. R. et al. Importance of sample preparation for molecular diagnosis of lyme borreliosis from urine. J Clin Microbiol, v. 40, p. 4581-4, 2002.

6. CARLQUIST, J. F. et al. An evaluation of nine genetic variants related to metabolism and mechanism of action of warfarin as applied to stable dose prediction. J Thromb Thrombolysis, 2010. [Epub ahead of print]

7. CLINICAL AND LABORATORY STANDARDS INSTITUTE (CLSI). Collection, transport, preparation and storage of specimens for molecular methods; approved guideline. CLSI document MM13-A. Pennsylvania, USA: Clinical and Laboratory Standards Institute, 2005.

8. DEBEY-PASCHER, S.; EGGLE, D.; SCHULTZE, J. L. RNA stabilization of peripheral blood and profiling by bead chip analysis. Methods Mol Biol, v. 496, p. 175-210, 2009.

9. FARKAS, D. H. et al. Specimen collection and storage for diagnostic molecular pathology investigation. Arch Pathol Lab Med, v. 120, p. 591-6, 1996.

10. FEIGELSON, H. S. et al. Determinants of DNA yield and quality from buccal cell samples collected with mouthwash. Cancer Epidemiol Biomarkers Prev, v. 10, p. 1005-8, 2001.

11. FERNANDES, J. V. et al. Comparação de três protocolos de extração de DNA a partir de tecido fixado em formol e incluído em parafina. Jornal Brasileiro de Patologia e Medicina Laboratorial, v. 40, p. 141-6, 2004.

12. GILBERT, M. T. et al. The isolation of nucleic acids from fixed, paraffin-embedded tissues which methods are useful when? PLoS One, v. 2, p. e537, 2007.

13. GOLOGAN, A. et al. Performance of the revised Bethesda guidelines for identification of colorectal carcinomas with a high level of microsatellite instability. Arch Pathol Lab Med, v. 129, p. 1390-7, 2005.

14. HENEGHAN, C. etal. Optimal loading dose for the initiation of warfarin: a systematic review. BMC Cardiovasc Disord, v. 10, p. 18, 2010.

15. HOFFMANN, M. S. et al. Microarray studies of genomic oxidative stress and cell cycle responses in obstructive sleep apnea. Antioxid Redox Signal, v. 9, p. 661-9, 2007.

16. HOLLENSEAD, S. C.; LOCKWOOD, W. B.; ELIN, R. J. Errors in pathology and laboratory medicine: consequences and prevention. J Surg Oncol, v. 88, p. 161-81, 2004.

17. HONDA, K.; ROEWER, L.; de KNIJFF, P. Male DNA typing from 25-year-old vaginal swabs using $Y$ chromosomal STR polymorphisms in a retrial request case. J Forensic Sci, v. 44, p. 868-72, 1999.

18. JAIN, K. K. Molecular diagnostic market heating up. Genetic Engineering and Biotechnology News, v. 30, n. 7. Disponível em: <http://www.genengnews.com/ gen-articles/molecular-diagnostic-market-heatingup/3234/?page=1>. Acesso em: 29 jun. 2010.

19. KÄSER, M. et al. Optimized DNA preparation from mycobacteria. Cold Spring Harb Protoc, 2010.

20. LENZINI, P. et al. Integration of genetic, clinical, and INR data to refine warfarin dosing. Clin Pharmacol Ther, v. 87, p. $572-8,2010$.

21. LIMDI, N. A. et al. Warfarin pharmacogenetics: a single VKORC1 polymorphism is predictive of dose across 3 racial groups. Blood, v. 115, p. 3827-34, 2010.

22. MICHALCZYK, A. et al. Fresh and cultured buccal cells as a source of mRNA and protein for molecular analysis. Biotechniques, v. 37, p. 262-9, 2004.

23. OKELLO, J. B. et al. Comparison of methods in the recovery of nucleic acids from archival formalin-fixed paraffinembedded autopsy tissues. Anal Biochem, v. 400, p. 110-7, 2010.

24. RIEMANN, K. et al. Comparison of manual and automated nucleic acid extraction from whole-blood samples. J Clin Lab Anal, v. 21, p. 244-8, 2007.

25. SATSANGI, J. et al. Effect of heparin on polymerase chain reaction. Lancet, v. 343, p. 1509-10, 1994.

26. SBPC/ML. Norma PALC - Lista de verificação em biologia molecular 2008.

27. SBPC/ML. Recomendações da Sociedade Brasileira de Patologia Clínica para Coleta de Sangue Venoso. 2 ed. Barueri, SP: Minha Editora, 2010.

28. SCHUURMAN, T. et al. Comparative evaluation of in-house manual, and commercial semi-automated and automated DNA extraction platforms in the sample preparation of human stool specimens for a Salmonella enterica 5-nuclease assay. J Microbiol Methods, v. 71, p. 238-45, 2007.

29. SHAROVA, L. V. et al. Database for mRNA half-life of 19 977 genes obtained by DNA microarray analysis of pluripotent and differentiating mouse embryonic stem cells. DNA Res, v. 16, p. 45-58, 2009.

30. SIMONATO, L. E. et al. Avaliação de dois métodos de extração de DNA de material parafinado para amplificação em PCR. Jornal Brasileiro de Patologia e Medicina Laboratorial, v. 43, p. 121-7, 2007.

31. SMITH, S.; MORIN, P. A. Optimal storage conditions for highly dilute DNA samples: a role for trehalose as a preserving agent. J Forensic Sci, v. 50, p. 1101-8, 2005.

32. SOARES-VIEIRA, J. A. et al. Y-STRs in forensic medicine: DNA analysis in semen samples of azoospermic individuals. J Forensic Sci, v. 52, p. 664-70, 2007. 
33. SOKOLL, L. J. et al. A multicenter evaluation of the PCA3 molecular urine test: pre-analytical effects, analytical performance, and diagnostic accuracy. Clin Chim Acta, v. 389, p. 1-6, 2008.

34. SUBRUNGRUANG, I. et al. Evaluation of DNA extraction and PCR methods for detection of Enterocytozoon bienuesi in stool specimens. J Clin Microbiol, v. 42, p. 3490-4, 2004.

35. SUFFYS, P. et al. Inhibition of the polymerase chain reaction by sputum samples from tuberculosis patients after processing using a silica-guanidiniumthiocyanate
DNA isolation procedure. Mem Inst Oswaldo Cruz, v. 96, p. 1137-9, 2001.

36. TANG, Y. W. et al. Comparative evaluation of three commercial systems for nucleic acid extraction from urine specimens. J Clin Microbiol, v. 43, p. 4830-3, 2005.

37. UZAN, C. et al. Fine-needle aspiration for nucleic acid-ased molecular analyses in breast cancer. Cancer Cytopathol, v. 117, p. 32-9, 2009.

38. YIP, L. et al. Loss of heterozygosity of selected tumor suppressor genes in parathyroid carcinoma. Surgery, v. 144, p. 949-55, 2008. 